\title{
PENGARUH CAPITAL ADEQUACY RATIO, NON-PERFORMING LOAN, NET INTEREST MARGIN, RETURN ON ASSETS, LOAN TO DEPOSIT RATIO, DAN BANK SIZE TERHADAP HARGA SAHAM PERUSAHAAN PERBANKAN YANG TERDAFTAR DI BURSA EFEK INDONESIA
}

\author{
Aries Santoso \\ Program Studi Magister Manajemen Universitas Tarumanagara \\ ariessantoso93@gmail.com \\ Carunia Mulya Firdausy \\ Program Studi Magister Manajemen Universitas Tarumanagara
}

Masuk : 03-12-2020, revisi : 17-12-2020, diterima untuk diterbitkan : 18-12-2020

\begin{abstract}
This study aims to analyze the influence of Capital Adequacy Ratio, NonPerforming Loan, Net Interest Margin, Return on Assets, Loan to Deposit Ratio, and Bank Size jointly and partially to Stock Price of banking sector company that listed on Indonesian Stock Exchange for period 2011-2018. This research used the purposive sampling method and obtained the 5 largest market capital banking sector companies as a sample. The analysis method used is multiple linear regression through SPSS 26 program. The results of this study show that Capital Adequacy Ratio, Non-Performing Loan, Net Interest Margin, Return On Assets, Loan to Deposit Ratio, and Bank Size have significant influence to stock price. While Capital Adequacy Ratio, Non-Performing Loan, Loan to Deposit Ratio partially have significant influence on the stock price. Meanwhile, Net Interest Margin, Return On Asset, and Bank Size have not a significant influence on the stock price of banking sector company that listed on the Indonesian Stock Exchange for period 2011-2018.

Keywords: Capital Adequacy Ratio, Non-Performing Loan, Net Interest Margin, Return On Assets, Loan to Deposit Ratio, Bank Size, Stock Price
\end{abstract}

Abstrak: Penelitian ini dimaksudkan untuk mencari pengaruh Capital Adequacy Ratio, NonPerforming Loan, Net Interest Margin, Return On Assets, Loan to Deposit Ratio, dan Bank Size mengenai keterkaitannya pada harga saham baik secara bersamaan maupun parsial terhadap harga saham perusahaan sektor bank yang ada di Bursa Efek Indonesia untuk periode penelitian 2011 - 2018. Penelitian ini mengunakan metode purposive sampling yang ditetapkan sebanyak 5 perusahaan sektor perbankan yang memiliki kapitalisasi pasar terbesar sebagai sampel. Metode analisis yang dipakai menggunakan regresi linear berganda melalui bantuan SPSS 26. Hasil penelitian membuktikan secara simultan, Capital Adequacy Ratio, NonPerforming Loan, Net Interest Margin, Return On Assets, Loan to Deposit Ratio, dan Bank Size berpengaruh signifikan terhadap harga saham. Sementara secara parsial, Capital Adequacy Ratio, Non-Performing Loan, dan Loan to Deposit Ratio berpengaruh terhadap harga saham. Sedangkan Net Interest Margin, Return On Asset, dan Bank Size tidak berkaitan terhadap harga saham sektor bank yang terdaftar di Bursa Efek Indonesia periode 2011-2018.

Kata Kunci: Capital Adequacy Ratio, Non-Performing Loan, Net Interest Margin, Return On Assets, Loan to Deposit Ratio, Bank Size, Stock Price

\section{PENDAHULUAN}

Harga saham sektor bank yang ada di Bursa Efek Indonesia (BEI) nilainya berfluktuasi. Perusahaan yang memiliki faktor fundamental yang baik tidak menjamin harga sahamnya akan ikut terpengaruh (Sparta 2000, p.57).

Adapun penelitian sebelumnya mengenai faktor-faktor yang dapat mempengaruhi 
pergerakan harga saham, seperti yang diungkapkan oleh Anggela A. Adam (2018), misalnya mendapatkan bahwa Return on Asset berpengaruh terhadap harga saham, dan Capital Adequacy Ratio serta Loan to Deposit Ratio tidak berpengaruh signifikan dengan harga saham.

Penelitian ini dilakukan untuk melengkapi penelitian sebelumnya. Adapun yang menjadi pembeda antara penelitian ini dan penelitian yang telah ada yaitu pada subjek penelitian yang diteliti oleh peneliti terdahulu adalah semua perusahaan sektor perbankan, sedangkan penelitian saat ini lebih berfokus pada 5 perusahaan sektor perbankan yang memiliki kapitalisasi pasar besar. Saham yang memiliki kapitalisasi pasar besar akan menarik bagi investor untuk mengikutsertakan modalnya dalam jangka panjang, hal ini dikarenakan adanya potensi pertumbuhan perusahaan yang baik selain pembagian dividen serta memiliki tingkat risiko yang rendah.

Tujuan dilakukannya penelitian ini adalah untuk mengkaji pengaruh Capital Adequacy Ratio, Non-Performing Loan, Net Interest Margin, Return on Assets, Loan to Deposit Ratio, dan Bank Size secara parsial dan bersamaan terhadap harga saham pada perusahaan sektor bank yang terdaftar di BEI periode 2011- 2018.

\section{TINJAUAN PUSTAKA DAN HIPOTESIS}

\section{Pengaruh Capital Adequacy Ratio (CAR) Terhadap Harga Saham}

Dendawijaya (2005, p.121) mengungkapkan bahwa CAR merupakan rasio yang dipakai untuk mengukur seberapa besar aktiva yang dimiliki oleh bank yang memiliki risiko (pinjaman, surat berharga, penyertaan, dan tagihan pada bank lain) yang dibiayai dari modal yang dimiliki bank sendiri selain memperoleh dana dari sumber lainnya diluar bank, saperti perolehan dana dari masyarakat. Apabila CAR bank naik dari waktu ke waktu akan berdampak pada kepercayaan investor yang dapat mempengaruhi permintaan harga saham yang mengakibatkan kenaikan harga saham.

$$
\mathrm{CAR}=\frac{\text { Modal Bank }}{\text { Aktiva Tertimbang Menurut Risiko }} \times 100 \%
$$

\section{Pengaruh Non-Performing Loan (NPL) Terhadap Harga Saham}

Iswi Hariyani (2010) menyatakan bahwa rasio NPL digunakan untuk mengukur kemampuan yang dimiliki oleh bank dalam rangka mengelola kredit macet yang disalurkan bank. Apabila rasio NPL tinggi, maka dapat dikatakan jumlah kredit yang bermasalah semakin besar, sehingga akan menjadikan kesehatan bank dan ratingnya akan turun, dan tentunya akan menjadikan harga saham bank tersebut turun, dan dengan besarnya tingkat NPL, maka risiko kredit juga akan meningkat yang akan mempengaruhi risiko secara keseluruhan. Jadi, NPL berpengaruh terhadap harga saham.

$$
\mathrm{NPL}=\frac{\text { Kredit Kurang Lancar }+ \text { Kredit Diragukan }+ \text { Kredit Macet }}{\text { Total Kredit Yang Diberikan }} \times 100 \%
$$

\section{Pengaruh Net Interest Margin (NIM) Terhadap Harga Saham}

Menurut Pandia (2012, p.71), rasio NIM digunakan untuk mencari seberapa jauh kemampuan yang dimiliki oleh manajemen bank dalam rangka mengelola aktiva produktif yang dimilikinya dalam rangka menghasilkan pendapatan bunga bersih. Tingginya nilai rasio NIM maka dapat disimpulkan semakin tinggi tingkat efektivitas bank dalam penempatan aktiva produktif dalam bentuk kredit dan akan semakin besar pula pemasukan yang diperoleh dari penghasilan bunga yang akan mempengaruhi minat investor untuk mengikutsertakan modalnya pada perusahaan perbankan.

$$
\mathrm{NIM}=\frac{\text { Pendapatan Bunga Bersih }}{\text { Aktiva Produktif }} \times 100 \%
$$




\section{Pengaruh Return on Assets (ROA) Terhadap Harga Saham}

Menurut Horne dan Wachowicz (2005, p.235), rasio ROA digunakan untuk mengukur tingkat efektivitas perusahaan dalam rangka memperoleh laba dari aktiva yang dimiliki dan kemampuan untuk menghasilkan laba yang berasal dari modal kerja yang telah diinvestasikan. Hal ini juga diungkapkan oleh Irham Fahmi (2013, p.137), yang menyatakan bahwa ROA dihitung untuk menentukan sampai sejauh mana investasi pada suatu perusahaan dapat menghasilkan pengembalian keuntungan sesuai/diharapkan. Semakin besar tingkat ROA mengukur keuntungan yang berhasil dicapai perusahaan, sehingga dapat menarik minat investor untuk menyalurkan modalnya pada perusahaan tersebut

$$
\text { ROA }=\frac{\text { Laba Setelah Pajak }}{\text { Total Asset }} \times 100 \%
$$

\section{Pengaruh Loan to Deposit Ratio (LDR) Terhadap Harga Saham}

Pengelolaan LDR yang baik akan berpengaruh terhadap peningkatan harga saham, karena dana yang diberikan kepada masyarakat seimbang proporsinya (kredit) dengan dana yang diperoleh dari masyarakat (deposit) yang mengindikasikan kepercayaan masyarakat juga meningkat.

$$
\text { LDR }=\frac{\text { Jumlah Kredit yang Diberikan }}{\text { Total Dana Pihak Ketiga }} \times \quad 100 \%
$$

\section{Pengaruh Bank Size Terhadap Harga Saham}

Semakin besar ukuran perusahaan, maka mengindikasikan bahwa perusahaan telah berkembang, hal ini menyebabkan investor akan memberikan respon positif yang akan berdampak pada peningkatan nilai perusahaan. Tingkat nilai perusahaan yang besar dalam persaingan menunjukkan bahwa daya saing perusahaan lebih tinggi daripada perusahaan dengan ukuran kecil, investor akan menanggapi dengan positif sehingga nilai saham akan mengalami peningkatan.

$$
\text { Bank Size }=\quad \operatorname{Ln}(\text { Total Asset })
$$

Catriwati (2017) mengkaji pengaruh CAR, ROA, LDR, NIM, NPM, dan Asset Growth mengenai pengaruhnya terhadap harga saham perbankan yang terdaftar di Bursa Efek Indonesia. Secara parsial, variabel ROA dan NIM mempunyai pengaruh signifikan terhadap harga saham. Sedangkan CAR, LDR, NPL, dan Asset Growrh tidak berdampak pada harga saham.

Dari penelitian-penelitan terdahulu terdapat tujuh hipotesis alternatif pada penelitian ini:

H1 : Capital Adequacy Ratio mempunyai pengaruh pada harga saham sektor bank yang terdaftar di BEI selama periode 2011-2018.

H2 : Non-Performing Loan mempunyai pengaruh pada harga saham sektor bank yang terdaftar di BEI selama periode 2011-2018.

H3 : Net Interest Margin mempunyai pengaruh pada harga saham sektor bank yang terdaftar di BEI selama periode 2011-2018.

H4 : Return on Assets mempunyai pengaruh pada harga saham sektor bank yang terdaftar di BEI selama periode 2011-2018.

H5 : Loan to Deposit Ratio mempunyai pada terhadap harga saham sektor bank yang terdaftar di BEI selama periode 2011-2018.

H6 : Bank Size memiliki pengaruh terhadap harga saham sektor bank yang terdaftar di BEI selama periode 2011-2018.

H7 : Capital Adequacy Ratio, Non-Performing Loan, Net Interest Margin, Return on Assets, Loan to Deposit Ratio, dan Bank Size secara bersama-sama berpengaruh terhadap harga saham sektor perbankan yang ada di BEI selama periode 2011-2018. 


\section{METODOLOGI PENELITIAN}

Populasi penelitian merupakan perusahaan perbankan yang ada di BEI periode 20112018. Jumlah populasi pada penelitian ini sebanyak 43 perusahaan. Pemilihan sampel yang dilakukan berdasarkan metode purposive sampling, yakni pengambilan sampel yang berdasarkan pada kriteria tertentu.

Penelitian ini menggunakan sumber data sekunder, data penelitian diperoleh secara tidak langsung dari objek yang diteliti. Data tersebut diperoleh dengan mengunduhnya dari dokumentasi Bursa Efek Indonesia (BEI) melalui website www.idx.co.id dan www.financeyahoo.com.

Dari data yang dikumpulkan dipilih data harga saham (Y) sebagai variabel terikat dan CAR $\left(\mathrm{X}_{1}\right)$, NPL $\left(\mathrm{X}_{2}\right)$, NIM $\left(\mathrm{X}_{3}\right)$, ROA $\left(\mathrm{X}_{4}\right)$, LDR $\left(\mathrm{X}_{5}\right)$, dan Bank Size $\left(\mathrm{X}_{6}\right)$ sebagai variabel bebas.

Secara statistik persamaan dari semua variabel adalah sebagai berikut:

$$
\mathrm{Y}=\ln \alpha+\beta_{1} \ln \mathrm{X}_{1}+\beta_{2} \ln \mathrm{X}_{2}+\beta_{3} \ln \mathrm{X}_{3}+\beta_{4} \ln \mathrm{X}_{4}+\beta_{5} \ln \mathrm{X}_{5}+\beta_{6} \ln \mathrm{X}_{6}+\varepsilon
$$

Dimana:

$\mathrm{Y}$

$\ln \alpha$

$\beta_{1}, \beta_{2}, \beta_{3}, \beta_{4}, \beta_{5}$

$\ln \mathrm{X}_{1}$

$\ln \mathrm{X}_{2}$

$\ln \mathrm{X}_{3}$

$\ln \mathrm{X}_{4}$

$\ln \mathrm{X}_{5}$

$\ln \mathrm{X}_{6}$

$\varepsilon$

: Harga Saham (Rupiah)

: log natural konstanta

: Koefisien regresi linier

: log natural Capital Adequacy Ratio (persen)

: log natural Non-Performing Loan (persen)

: log natural Net Interest Margin (persen)

: log natural Return on Assets (persen)

: log natural Loan to Deposit Ratio (persen)

: Bank Size (log natural Total Asset)

: Koefisien Error

Metode analisis data penelitian ini menggunakan bantuan program pengolahan data Statistical Package for Social Science (SPSS) versi 26.

\section{ANALISIS DAN BAHASAN TEMUAN}

Berdasarkan hasil penelitian diperoleh model persamaaan sebagai berikut:

$\ln \mathrm{Y}=\ln 14,047+2,319 \ln \mathrm{X}_{1}-0,479 \ln \mathrm{X}_{2}-0,023 \ln \mathrm{X}_{3}+0,112 \ln \mathrm{X}_{4}-2,273 \ln \mathrm{X}_{5}-0,139 \ln \mathrm{X}_{6}$

Dari persamaan di atas dapat diperhatikan bahwa CAR memberikan kontribusi pengaruh pada harga saham sebesar 2,319. Jika CAR naik sebesar 1 persen maka harga saham akan meningkat sebesar 2,319 dan demikian juga sebaliknya dengan asumsi variabel independen lainnya dianggap tetap atau sama dengan nol. NPL juga berkontribusi mempengaruhi harga saham sebesar -0,479 satuan. Jika NPL naik 1 persen maka akan menyebabkan penurunan pada perubahan variabel harga saham sebesar 0,479 dan demikian juga sebaliknya dengan asumsi variabel independen lainnya dianggap tetap atau sama dengan nol.

NIM mempengaruhi harga saham sebesar -0,023. Jika NIM naik 1 persen maka akan menyebabkan penurunan pada variabel harga saham sebesar 0,023 dan demikian juga sebaliknya. ROA berkontribusi mempengaruhi harga saham sebesar 0,112. Jika ROA naik 1 persen maka akan menyebabkan peningkatan pada variabel harga saham sebesar 0,112 dan demikian juga sebaliknya. LDR berkontribusi mempengaruhi harga saham sebesar -2,273. Jika LDR naik 1 persen maka akan menyebabkan penurunan pada variabel harga saham sebesar 2,273 dan demikian juga sebaliknya. Bank Size berkontribusi mempengaruhi harga saham sebesar -0,139. Jika Bank Size naik satu persen maka akan menyebabkan penurunan pada variabel harga saham sebesar 0,139 dan demikian juga sebaliknya.

Secara parsial CAR, NPL, dan LDR yang memiliki pengaruh signifikan pada harga saham perusahaan perbankan. Sedangkan NIM, ROA, dan Bank Size tidak mempengaruhi harga saham secara signifikan (Tabel 1). 
Tabel 1

Hasil Uji t (t test)

\begin{tabular}{|c|c|c|c|c|c|c|}
\hline \multicolumn{7}{|c|}{ Coefficients ${ }^{a}$} \\
\hline \multirow{2}{*}{\multicolumn{2}{|c|}{ Model }} & \multicolumn{2}{|c|}{ Unstandardized Coefficients } & \multirow{2}{*}{$\begin{array}{c}\text { Standardized } \\
\text { Coefficients }\end{array}$} & \multirow[b]{2}{*}{$\mathrm{t}$} & \multirow[b]{2}{*}{ Sig. } \\
\hline & & B & Std. Error & & & \\
\hline \multirow[t]{7}{*}{1} & (Constant) & 14.047 & 4.795 & & 2.930 & .006 \\
\hline & Ln_BS & -.139 & .127 & -.165 & -1.091 & .283 \\
\hline & Ln_CAR & 2.319 & .579 & .595 & 4.008 & .000 \\
\hline & Ln_NPL & -.479 & .184 & -.444 & -2.602 & .014 \\
\hline & Ln_ROA & .112 & .350 & .049 & .319 & .752 \\
\hline & Ln_LDR & -2.273 & 991 & -.386 & -2.293 & .028 \\
\hline & Ln_NIM & -.023 & .340 & -.010 & -.069 & .946 \\
\hline
\end{tabular}

a. Dependent Variable: Ln_HS

Sumber: Diolah dari data penelitian

Jika dilihat secara bersama sama, diperoleh hasil bahwa keenam variabel bebas secara bersama sama memiliki pengaruh terhadap harga saham. Hal ini dapat diketahui dari tabel hasil uji F (Tabel 2).

Tabel 2

Hasil Uji F (F test) ANOVA $^{\text {a }}$

\begin{tabular}{|rl|r|r|r|r|r|}
\hline \multicolumn{1}{|l|}{ Model } & & Sum of Squares & df & Mean Square & F & Sig. \\
\hline 1 & Regression & 6.860 & 6 & 1.143 & 5.036 & $.001^{\mathrm{b}}$ \\
& Residual & 7.492 & 33 & .227 & & \\
& Total & 14.352 & 39 & & & \\
\hline
\end{tabular}

a. Dependent Variable: Ln_HS

b. Predictors: (Constant), Ln_NIM, Ln_ROA, Ln_CAR, Ln_BS, Ln_LDR, Ln_NPL

Sumber: Diolah dari data penelitian.

Berdasarkan hasil uji koefisien determinasi diketahui nilai $R$-squared $\left(\mathrm{R}^{2}\right)$ sebesar 38,3\%. Angka $\left(\mathrm{R}^{2}\right)$ yang diperoleh mendekati 0 menunjukan hubungan yang lemah. Nilai $R^{2}$ (koefisien determinasi) sebesar $38,3 \%$. Hal ini menunjukkan bahwa persentase pengaruh variabel independen (CAR, NPL, NIM, ROA, LDR, dan Bank Size) terhadap variabel dependen (Harga Saham) sebesar $38,3 \%$. Sementara selebihnya $61,7 \%$ dipengaruhi oleh faktor lainnya di luar model penelitian ini.

\section{KESIMPULAN DAN SARAN \\ Kesimpulan}

Dengan menggunakan uji t diperoleh hasil bahwa Capital Adequacy Ratio, NonPerforming Loan, dan Loan to Deposit Ratio memiliki pengaruh signifikan terhadap harga saham sektor perbankan. Sedangkan Return on Asset, Net Interest Margin dan Bank Size tidak memiliki pengaruh yang signifikan pada harga saham sektor perbankan secara parsial. Namun secara bersama-sama seluruh variabel bebas yang diestimasi dalam studi ini berpengaruh signifikan terhadap harga saham sektor perbankan yang terdaftar di BEI.

\section{Saran}

Dari hasil penelitian, maka saran yang dapat diberikan adalah sebagai berikut:

1. Perusahaan perbankan diharapkan perlu memperhatikan rasio CAR, NPL, dan LDR agar harga saham meningkat.

2. Penelitian selanjutnya perlu menambah atau mengurangi jumlah variabel karena koefisien determinasi yang diperoleh hanya sebesar 38,3 persen.

\section{DAFTAR PUSTAKA}

Adam, A. A. (2018). Analisis pengaruh rasio CAMEL terhadap harga saham pada perusahaan perbankan yang terdaftar di BEI Tahun 2010-2013. E-Jurnal Sariputra, 5(1), 67-66. 
Catriwati. (2017). Pengaruh capital adequacy ratio (CAR), return on asset (ROA), loan to deposit ratio (LDR), net interest margin (NIM), non-performing loan (NPL), dan asset growth terhadap harga saham perbankan yang terdaftar di Bursa Efek Indonesia. Jurnal Intra-Tech, 1(2), 76-91.

Dendawijaya, L. (2005). Manajemen Perbankan ( $2^{\text {nd }}$ ed.). Bogor: Ghalia Indonesia.

Fahmi, I. (2013). Analisis Laporan Keuangan. Bandung: Alfabeta.

Harahap, D. A., \& Hairunnisah, A. I. (2017). Pengaruh NPL, LDR, GCG, NIM, ROA, ROE, CAR, BOPO terhadap harga saham pada perusahaan perbankan yang terdaftar di Bursa Efek Indonesia dari tahun 2010-2014. Jurnal Dimensi, 6(1), 22-40.

Hariyani, I. (2010). Restrukturisasi dan Penghapusan Kredit Macet. Jakarta: PT Elex Media Komputindo.

James, H., \& Wachowicz, J. (2005). Prinsip-prinsip Manajemen Keuangan (Fundamental of Financial Management) (12 ${ }^{\text {th }}$ ed.). Diterjemahkan oleh Dewi Fitriasari. Jakarta: Salemba Empat.

Pandia, F. (2012). Manajemen Dana dan Kesehatan Bank. Jakarta: Penerbit Rineka Cipta.

Sparta. (2000). Pengaruh faktor-faktor fundamental lembaga keuangan bank terhadap harga sahamnya di Bursa Efek Jakarta. Jurnal Akuntansi, 5(1), 54-69.

https://www.idx.co.id/

https://finance.yahoo.com/ 